\title{
The Mode of German Vocational education and the Enlightenment
}

\author{
SUN Yan \\ Associate Professor of School of International Exchange \\ Shanghai Second Polytechnic University \\ Shanghai, China \\ sy701017@163.com
}

\begin{abstract}
Nowadays, vocational education development is a matter of great urgency in China. Because of starting later, vocational education cannot establish a stable system of running school, serving the society, training talents and teachers; it should propose the successful experience of the world to promote the effective healthy and fast development. On the base of analysis of German vocational education mode, especially take an example of DHBW curriculum of Event Management, this study was performed to find its reference for the modern vocational education development in China. The references are also new and original; they are promoting the depth of the cooperation of the industry and vocational colleges with the government guidance, reforming the mode of talent cultivation and strengthening the policy support and supervision to guarantee.
\end{abstract}

Keywords-German vocational education mode; China present situation; enlightment; developement

\section{INTRODUCTION}

At present, Chinese government deployed to accelerate the development of modern vocational education, put forward reform ideas to run vocational education, which is significant to enhance the labor force of the employment of entrepreneurship, industry quality and comprehensive national strength. China must adhere to improve the quality, promote employment, service development oriented, play a good government guidance, standardization and supervision role, fully mobilize social forces to attract more resources to the vocational education development, to accelerate the development of modern vocational education with technological progress.

Germany is one of the most developed countries in the world, its professional talent training mode is unique. German vocational education connotation is wide, which includes continuing education, on-the-job training, promotion and training and re-employment study, etc. ${ }^{[1]}$ The writer studied its referential nature in China according to an analysis of the training mode of Vocational Education in Germany to provide reference for the development of modern vocational education in China.

This research is supported by the key subjects of Tourism Management in Shanghai Second Polytechnic University (Approval number:XXK2D1303)

\section{Analysis on The Cultivation Mode of Vocational EDUCATION IN GERMANY}

\section{A. Legal system of Vocational Education}

German "Vocational Education Law" is rigorous, standardized, operational, and it has played a great role in promoting and promoting its vocational education. It has a clear and specific requirements for the cultivation of vocational education, funding sources, teacher qualifications, examination methods, management supervision and research statistics, and formed a set of laws and the rule of law in education, law breakers of the legal system, promote the German Vocational Education in a healthy and orderly development. ${ }^{[2]}$

\section{B. Dual system of cultivation mode}

Dual system is the main form of German vocational education, refers to the students signed a contract with the enterprises after the completion of the basic education, study the professional skills and knowledge in the job of the enterprise, also study the vocational professional theory, general cultural knowledge education and skills in vocational colleges. It is a vocational education system which is closely integrated with the school, the theory knowledge and the practical skills. The main characteristic of dual system is that the running system takes enterprise as the main body, the standard of talent training takes vocational ability as the core, and the operating mechanism is based on market and social needs. When students graduate, two types of certificates can be obtained, one is the certificate issued by the Industry Association for world recognition, such as technical worker certificate obtained by passing the exam. The other is the certificate issued by the school and the training certificate issued by the enterprise. German enterprises take charge 70\% vocational education cost of the dual system. Not only can the enterprise obtain the high skilled staff, but also provide a lot of skills for the community. Generally, students study in German vocational school for three years, one year and a half to study theory knowledge, one year and a half to participate in the practice activities, usually three months classes, and three months practice per semester to ensure the students to improve their theoretical and practical ability. The dual system has promoted the rapid development of German economy to the 
maximum extent. There are also inadequacies, which are subject to economic constraints. Once the economic crisis occurs, the enterprise employment demand reduction, will affect the enterprise initiative to participate in vocational education. $^{[3]}$

\section{Seamless docking of the course content and industry requirements}

Preparation of German vocational education curriculum should be promulgated by the state and the state of occupational classification regulations and training regulations as the basis, but also embody the characteristics of enterprise post, and accept the assessment of the industry association. Its course contents broke the subject standard. ${ }^{[4]}$ Take the job of enterprise post to determine the content of course, the module of curriculum system and comprehensive characteristic is very distinct. It is a vocational ability standard curriculum system. The author takes Event Management of DHBW as an example, its teaching contents are business administration, exhibition management, conference management, large-scale activity management, display design and build these five modules which meet the requirement of industry associations and enterprises. After completion of each module, with the corresponding practice, students can have the required working ability of this module. See Table 1 for the courses.

TABLE I. DHBW CURRICULUM OF EVENT MANAGEMENT

\begin{tabular}{|c|c|}
\hline Modules & Main curriculum \\
\hline $\begin{array}{c}\text { Business } \\
\text { Administration }\end{array}$ & $\begin{array}{c}\text { Marketing management; Organizational } \\
\text { management science; Human resource } \\
\text { management; Statistics; Strategic management; } \\
\text { Economics; Accounting; Law basis; Computer; } \\
\text { Lecture on special subject }\end{array}$ \\
\hline $\begin{array}{l}\text { Exhibition } \\
\text { management }\end{array}$ & $\begin{array}{l}\text { Exhibition project management; Financial } \\
\text { accounting; Exhibition logistic service; Venue } \\
\text { planning; Market Research; Strategy and plan } \\
\text { implementation; Management of exhibitors }\end{array}$ \\
\hline $\begin{array}{l}\text { Conference } \\
\text { management }\end{array}$ & $\begin{array}{l}\text { Conference project management; Conference } \\
\text { financial budget; Choice of venue; PCO; } \\
\text { Conference insurance and law; Service provider } \\
\text { management; Conference summary processing }\end{array}$ \\
\hline $\begin{array}{c}\text { Large activity } \\
\text { management }\end{array}$ & $\begin{array}{l}\text { Large activity project management; Large } \\
\text { activity concept and innovation; Activity venues } \\
\text { and facilities; Activity agent management; } \\
\text { Meeting effect survey; Music and entertainment } \\
\text { design; Activity guide }\end{array}$ \\
\hline $\begin{array}{l}\text { Display design } \\
\text { and build }\end{array}$ & $\begin{array}{l}\text { Booth construction preliminary work; Booth } \\
\text { design; Booth safety management; Booth } \\
\text { construction program; Booth accounting; Booth } \\
\text { Logistics; Booth activity design }\end{array}$ \\
\hline
\end{tabular}

\section{Double division type of teaching team}

The teacher team of German higher vocational education is composed of full-time teachers and engineering technicians and administrators. The biggest characteristic of the teaching team is the full-time teachers accounted the minority, and the parttime teachers of enterprises accounted for the vast majority. ${ }^{[5]}$ These teachers not only have solid professional knowledge and rich practical experience, but also close to the combination of the new knowledge of the enterprise production and management, technology management and teaching content. Let the students learn in order to practice.

\section{E. The continuity level of the vocational education system}

German vocational education has formed a spiral, from the low to the high level of the system. The higher vocational and technical education is based on the low level of secondary vocational education with certain professional experience as the premise. Junior middle school students can take advantage of the knowledge and skills they have learned to work on the relative occupations after 1-3 years of dual system of vocational education or training, or accept the higher vocational and technical education after the enterprise practice. This high and low vocational education mode is varied and flexible, which provides students with equal competition and more advanced studies. At the same time, the level of Vocational Education in Germany and the common education, contact each other. ${ }^{[6]}$ Students from vocational and technical colleges can obtain the opportunity to enter the ordinary institution for further studies, and embodies the education fairness of the whole society.

\section{The PRESENT SituAtion OF ChINA ProfESSIONAL TALENTS CULTIVATION}

At present, the Chinese government has proposed to establish the important position of Vocational Education in the national personnel training system, and want to promote the formation of "advocating proficiency in a particular line, with the ability to not only academic" social atmosphere to inspire young people's enthusiasm to learn vocational skills. Enterprise in the cultivation of professional talent has always been in a subordinate position, and vocational college is the main trainer. The characteristics of the personnel training in these vocational colleges are as follows:

\section{A. China's vocational education laws and regulations system not perfect}

There have never been any new changes of occupation education law in our country after promulgation in 1996. As an important law in the field of Vocational Education, it is lack of operating rules on the school enterprise cooperation and other aspects of the relevant provisions of the general summary with the implementation of the larger space. Although the legal system of Vocational Education in China has been formed, but the legal system of our country's vocational education is still not high. The vocational education system in China is in the legal system of vocational education, functions and law enforcement, legal awareness, legal supervision of the four aspects still need to be improved.

\section{B. The curriculum not reflected in the professional ability orientation}

In the domestic vocational colleges, there is the basis of order form cultivation, school enterprise cooperation. But the main body is still school. Curriculum is still subject to subject orientation under the guidance of the concept of "wide caliber". Schools value knowledge and despise ability cultivation. The author took Event Management of Shanghai Second 
Polytechnic University as an example, found it want to cultivate the students as high skilled personnel for the management of application type exhibition project with morality and political literacy earlier, then theoretical knowledge and practical skills. According to following Table 2, the author found this type of Applied Undergraduate Colleges and universities emphasized the students' theoretical basis, especially emphasized on the economics, mathematics and other basic courses learning. Real professional theory and practice of the proportion accounted for only $55 \%$.

TABLE II. SSPU CURRICULUM OF EVENT MANAGEMENT

\begin{tabular}{|c|c|c|}
\hline Modules & Proportion & Main curriculum \\
\hline $\begin{array}{c}\text { Public } \\
\text { courses }\end{array}$ & $15 \%$ & $\begin{array}{c}\text { Marx doctrine; Military theory; } \\
\text { Sports; Computer application; etc. }\end{array}$ \\
\hline $\begin{array}{c}\text { Basic } \\
\text { courses }\end{array}$ & $30 \%$ & $\begin{array}{c}\text { Calculus; Management; Economics; } \\
\text { Accounting; Marketing; Human } \\
\text { resource; English etc. }\end{array}$ \\
\hline $\begin{array}{c}\text { Specialized } \\
\text { courses }\end{array}$ & $40 \%$ & $\begin{array}{c}\text { Activity planning; Exhibition } \\
\text { planning; Conference planning; } \\
\text { Venue management; Introduction to } \\
\text { large events; Display design; } \\
\text { Exhibition project management; } \\
\text { Market Research; Professional } \\
\text { English etc. }\end{array}$ \\
\hline $\begin{array}{c}\text { Practical } \\
\text { courses }\end{array}$ & $15 \%$ & $\begin{array}{c}\text { Usually within the prescribed time, } \\
\text { there is school enterprise } \\
\text { cooperation, and also the venue of } \\
\text { the internship. }\end{array}$ \\
\hline
\end{tabular}

\section{Problems in teaching staff}

There are two main problems in our country's vocational college teachers. One is irrational structure of title. The professor and associate professor proportion of the total number of professional teachers is low in higher vocational colleges. The reason is that the Vocational College Teachers' professional title evaluation is applied to the standard of ordinary colleges and Universities. The other is the proportion of teachers who have the knowledge and industry experience is very small. Because most teachers come from ordinary colleges and Universities, only are good at theory. They are lack of skill training of students' practical ability, and eventually led to the training of personnel is not fully adapted to business positions.

\section{The training of professional personnel and lifelong learning not formed}

From the developed countries and regions, the higher vocational training objectives can have a number of levels, Such as the Taiwan region of China's higher vocational colleges, there are undergraduate and graduate students three levels of training objectives. Some developed cities in China such as Shanghai began to try the cultivating modes of middle vocational to vocational school directly, vocational school to bachelor and middle vocational to bachelor directly. The quality of the training is still to be tested, far from forming the stereoscopic and solid structure of vocational training and lifelong learning.

\section{THE ENLIGHTENMENT OF GERMAN VOCATIONAL EDUCATION TO THE DEVELOPMENT OF VOCATIONAL EDUCATION IN CHINA}

Through investigation and analysis of the training mode of Vocational Education in Germany, The author thinks that it has the following enlightenment for the further development of China.

\section{A. Improve the legal system of Vocational Education}

In China, the government should improve and perfect the Vocational Education Law as the core of the clear, content, coordination and unity of the legal system of Vocational education. The author thinks the government should focus on the following aspects of the work. First, revise and improve the basic law of Vocational Education. Second, enact some vocational education law to make the legal system of vocational education more complete. Third, straighten out the relationship between the professional educations of the law, and make them coordinate with each other. Fourth, establish and improve the legal system of vocational education law revision, compilation, interpretation and repeal. Especially, the revision of the law of vocational education should take full account of the interests of the economic and social development, the needs of the educational reform and the interests of the enterprises and other participants. At the same time, we should improve the relevant legal system construction, and build a more benign vocational education law environment.

\section{B. Government oriented depth cooperation between enterprises and vocational colleges and Universities}

The biggest characteristic Vocational education of the "dual system" in Germany is that the government uses the legal regulations to guarantee the enterprise's active participation in the vocational education, make it clear that the enterprise has the responsibility and obligation to the social development. In fact, without the participation of enterprises, vocational education is not possible to obtain rapid development. The practice of cross enterprise training center in Dresden, Germany, is worth considering. But economically developed regions in China taking Yangtze River as the representative are fully qualified to participate in Vocational Education under the guidance of the government with a wide range of small and medium enterprises.

\section{Innovate talent cultivation mode in vocational colleges.}

Vocational colleges should strengthen the innovation of personnel training mode, the specific performance is as follows:

- Firstly, form the joint operating mechanism with enterprise. Vocational colleges and universities should establish a cooperative organization system, which is composed of schools and famous enterprises to form long-term operation mechanism of school enterprise joint training personnel, and achieve the depth of integration of enterprise in the training program design, curriculum development, teaching 
and implementation of the entire process of personnel training.

- Secondly, develop distinctive talents training program. Vocational colleges should jointly study and determine the training objectives and positioning of the pilot program with the enterprise, to research and development of the multi - level personnel training program with the characteristics of Vocational education according to the principle of "professional setting and industry demand docking, course content and professional standards docking, and teaching process and production process docking".

- Thirdly, build the curriculum system with the ability. Vocational colleges should focus on the cultivation of Applied Talents, control of the same profession and actively absorb industry experts and employers to participate in research, pay attention to basic knowledge and basic skills teaching and build the curriculum system with the ability. At the same time, strengthen the course construction of school enterprise cooperation to realize the "double certificate" system of academic certificate and professional qualification certificate.

- Fourthly, further promote the reform of teaching methods. Vocational colleges should strive to explore the teaching mode reform based on ability cultivation, promote the reform of teaching methods, such as project teaching method, case teaching method and so on through teaching team building. Professional courses can use as far as possible the real task and real case for teaching and the main topics of graduation design (or paper) can be from the actual production problems to promote scientific research and teaching interaction, and lead teachers to transform scientific research into teaching content.

- Fifthly, improve the practical teaching conditions. Strengthen the construction of experiment, practice and training base. We should focus on building the college students' practical education base for the cooperation between enterprises and enterprises to improve the effectiveness of practical teaching. The practice of guiding teachers' quantity and quality should be in accordance with the requirements of the construction of pilot projects.

- Sixthly, create characteristic teaching team. Occupation academy can establish the system of fulltime teachers learning in enterprises, have the plan of sending teachers to practice exercise to foster "double teacher" teacher. At the same time, hire some experts, scholars and experienced engineering and technical personnel from the industry, to form a special and combination of "double division" teaching team.

- Seventhly, deepen international exchanges and cooperation. Vocational colleges should in depth exchange and cooperate with the international high level professional, and introduce international recognition of vocational training standards to improve students' international competitiveness. At the same time, establish the student's overseas study and practice system, encourage students to actively participate in international exchanges.

- Finally, strengthen professional teaching management Vocational college should deepen the reform of professional teaching management system, change the practice which is not suitable to application oriented personnel training, and deepen the improvement of the system of teacher evaluation and student evaluation. Strengthen teaching process management, establish and improve the strict teaching management system. Introduce relevant certification standards and certificate the pilot program according to cooperating with international professional certification institution.

\section{Strengthen policy support and regulatory guarantees.}

The government should improve the financial investment mechanism, form and implement the classified standards for Vocational Colleges, strengthen supervision and assessment. Expand vocational college's autonomy in the professional setting and adjustment, personnel management, teacher evaluation, income distribution and other aspects. At the same time, increase support for vocational education, improve the financing policy, sound employment and employment policies to let the vocational education create a steady stream of talent dividend for the country and the community.

\section{CONCLUSION}

In a word, the development of vocational education is to promote the development of the national economy, adjust the structure and improve the livelihood of the people's livelihood improvement strategy. China should vigorously develop modern vocational education; effectively improve the market competitiveness of China's manufacturing. It may effectively set enterprises, colleges and social forces to do what little one can to help the development of the modern occupation education according to rely on government guidance and legislative protection.

\section{REFERENCES}

[1] Li Wenyou. The characteristics and Revelation of the training mode of Higher Vocational Education in Germany. Journal of Gansu Radio and Television University, 2013(9)

[2] Xiong Shuping. The characteristic and Revelation of German Vocational Education. Journal of Jilin engineering and technology Normal College, 2013(7) VOL29

[3] Mayu. The German dual system of occupation education development characteristics . Education Review,2012(6)

[4] Qu Tongying. The development history of German vocational education to the reference value of Chinese Vocational Education. Wuhu Journal of Career Technical College. 2011(1) VOL13

[5] Chenying. Construction of German Vocational Qualification Framework. Vocational Education Forum. 2010(21)

[6] Zhang Chengtao. On the value orientation of Vocational Education in the "Vocational" and "education" $[\mathrm{J}]$. Vocational education communication.2010(04) 